\title{
Phytoprotection
}

\section{Phytoalexins produced in the leaves of Capsella bursa-pastoris (shepherd's purse)}

\author{
L.D. Jimenez, W.A. Ayer et J.P. Tewari
}

Volume 78, numéro 3, 1997

URI : https://id.erudit.org/iderudit/706124ar

DOI : https://doi.org/10.7202/706124ar

Aller au sommaire du numéro

Éditeur(s)

Société de protection des plantes du Québec (SPPQ)l

ISSN

0031-9511 (imprimé)

1710-1603 (numérique)

Découvrir la revue

Citer cet article

Jimenez, L., Ayer, W. \& Tewari, J. (1997). Phytoalexins produced in the leaves of Capsella bursa-pastoris (shepherd's purse). Phytoprotection, 78(3), 99-103.

https://doi.org/10.7202/706124ar
Résumé de l'article

Trois phytoalexines, à savoir la camalexine $\left(\mathrm{C}_{11} \mathrm{H}_{8} \mathrm{~N}_{2} \mathrm{~S}\right)$, la

6-méthoxycamalexine $\left(\mathrm{C}_{12} \mathrm{H}_{10} \mathrm{~N}_{2} \mathrm{SO}\right)$ et la $\mathrm{N}$-méthylcamalexine $\left(\mathrm{C}_{12} \mathrm{H}_{10} \mathrm{~N}_{2} \mathrm{~S}\right)$ furent isolées de la bourse-à-pasteur (Capsella bursa-pastoris) après une exposition à l' Alternaria brassicae. La N-méthylcamalexine n'avait pas été rapportée précédemment. La production de phytoalexines chez la bourse-à-pasteur est reliée à sa résistance à l'A. brassicae, un agent pathogène causant, chez les crucifères cultivées, une maladie importante à plusieurs endroits dans le monde. 


\title{
Phytoalexins produced in the leaves of Capsella bursa-pastoris (shepherd's purse)
}

\author{
Luis D. Jimenez ${ }^{1}$, William A. Ayer ${ }^{1}$, and Jalpa P. Tewari²
}

Received 1997-01-24; accepted 1997-10-22

\section{PHYTOPROTECTION 78 : 99-103}

Three phytoalexins, camalexin $\left(\mathrm{C}_{11} \mathrm{H}_{8} \mathrm{~N}_{2} \mathrm{~S}\right)$, 6-methoxycamalexin $\left(\mathrm{C}_{12} \mathrm{H}_{10} \mathrm{~N}_{2} \mathrm{SO}\right)$, and $\mathrm{N}$-methylcamalexin $\left(\mathrm{C}_{12} \mathrm{H}_{10} \mathrm{~N}_{2} \mathrm{~S}\right)$, were isolated from shepherd's purse (Capsella bursa-pastoris) challenged by Alternaria brassicae. N-methylcamalexin has not been reported previously. Phytoalexin elicitation in shepherd's purse is associated with its resistance to $A$. brassicae, a pathogen which causes an important disease of cruciferous crops in many parts of the world.

\section{[Phytoalexines produites dans les feuilles du Capsella bursa-pastoris (bour- se-à-pasteur)]}

Trois phytoalexines, à savoir la camalexine $\left(\mathrm{C}_{11} \mathrm{H}_{8} \mathrm{~N}_{2} \mathrm{~S}\right)$, la 6-méthoxycamalexine $\left(\mathrm{C}_{12} \mathrm{H}_{10} \mathrm{~N}_{2} \mathrm{SO}\right)$ et la $\mathrm{N}$-méthylcamalexine $\left(\mathrm{C}_{12}^{8} \mathrm{H}_{10} \mathrm{~N}_{2} \mathrm{~S}\right)$ furent isolées de la bourse-à-pasteur (Capsella bursa-pastoris) après une exposition à l'Alternaria brassicae. La N-méthylcamalexine n'avait pas été rapportée précédemment. La production de phytoalexines chez la bourse-à-pasteur est reliée à sa résistance à $I^{\prime} A$. brassicae, un agent pathogène causant, chez les crucifères cultivées, une maladie importante à plusieurs endroits dans le monde.

\section{INTRODUCTION}

Alternaria brassicae causes the economically important black spot disease of Brassica crops in many parts of the world (Tewari 1991). Resistance in false flax [Camelina sativa (L.) Crantz] to Alternaria brassicae (Berk.) Sacc. is associated with the production of phytoalexins (Conn et al. 1988; Jejelowo et al. 1991). These phytoalexins were subsequently identified as camalexin and 6-methoxycamalexin (Browne et al. 1991). Camalexin was also later reported from Arabidopsis thaliana (L.) Heynh. challenged with Pseudomonas syringae pv. syringae van Hall (Tsuji et al. 1992). Because of recent interest in these compounds (Ayer et al. 1992; Gross 1993; Pedras et al. 1997; Tsuji et al. 1993), we report on the isolation of these compounds, and a new related compound, from shepherd's purse [Capsella bursa-pastoris (L.) Medic.] challenged with $A$. brassicae. Capsella bursa-pastoris is a common weed belonging to the family Brassicaeae and is highly resistant to $A$. brassicae and $A$. brassicicola Groves \& Skolko (Conn et al. 1988; Sigareva and Earle 1997; Tewari and Conn 1993). It is also cold tolerant, short life-cycled, and resistant to

1. Department of Chemistry, University of Alberta, Edmonton, Alberta, Canada T6G 2 G2

2. Department of Agricultural, Food and Nutritional Science, University of Alberta, Edmonton, Alberta, Canada T6G 2G2 
flea beetles (Bonfils et al. 1991; Sigareva and Earle 1997). All these are useful traits required for genetic improvement of Brassica crops and some recent studies have focussed on this area (Bonfils et al. 1991; Sigareva and Earle 1997).

\section{MATERIALS AND METHODS}

\section{General}

Melting points were determined on a Fisher-Johns melting point apparatus and are uncorrected. Infrared spectra (IR) were obtained using a Nicolet 750 FTIR spectrophotometer. Electron impact mass spectra (EIMS) were obtained using a Kratos AEI MS50 high resolution mass spectrometer. Ultraviolet (UV) spectra were recorded on a HewlettPackard 8450A diode array spectrometer. ${ }^{1} \mathrm{H}$ nuclear magnetic resonance spectra ( ${ }^{1} \mathrm{H}-\mathrm{NMR}$ ) were obtained using the following spectrometers: Bruker WH-360 (360 MHz), Bruker AM-400 $(400 \mathrm{MHz})$, and Varian Unity-500 (500 $\mathrm{MHz})$. Coupling constants are reported within $\pm 0.5 \mathrm{~Hz} .{ }^{13} \mathrm{C}$ nuclear magnetic resonance spectra were obtained on a Bruker AM-300 (75 MHz) and Bruker AM-400 (100.6 MHz). Carbon-13 multiplicities were determined using spin echo J-modulated experiments (APT or Attached Proton Test). Nuclear Overhauser Enhancement (NOE) experiments were determined in the difference mode in which a control spectrum was computer-subtracted from the irradiated spectrum after Fourier Transformation. Positive enhancements appear as signals possessing opposite phase with respect to the irradiated signal. Samples for NOE measurements were deoxygenated with argon for 10-20 min prior to use. Homonuclear decoupling experiments were performed using the Bruker DISNMR software package. High Performance Medium Pressure Liquid Chromatography (HPMPLC) was carried out on ACE Glass Inc. Michel-Miller equipment using a solvent pump from Fluid Metering Inc. model RP-SY. Compounds were detected using the ISCO V4 wavelength absorbance detector, and fractions were collected with the ISCO fraction collecter model 820 . High
Pressure Liquid Chromatography (HPLC) analyses were performed on a Waters 600E System Controller equipped with a $490 \mathrm{E}$ Programmable multiwavelength U.V. detector, and M730 Data Module.

\section{Plant material}

Plants were grown for 6-8 wk in a greenhouse at approximately $18 / 12^{\circ} \mathrm{C}$ (day/night) and a light intensity 400-600 $\mu \mathrm{mol} \cdot \mathrm{m}^{-2} \cdot \mathrm{s}^{-1}$. Plants were also collected from fields in Central Alberta. All plants used, including the siliques thereon, were lush green.

\section{Fungal strains}

Stock cultures of the fungus $A$. brassicae (University of Alberta Micro Fungus Herbarium culture \#UAMH 7476) were stored on slants in tubes on $\mathrm{V}-8$ juice agar $(200 \mathrm{~mL}$ filtered $\mathrm{V}-8$ juice, $0.05 \mathrm{~g}$ rose bengal, $3 \mathrm{~g} \mathrm{CaCO}_{3^{\prime}} 20 \mathrm{~g}$ agar, $800 \mathrm{~mL} \mathrm{H}_{2} \mathrm{O}$ ) at $4^{\circ} \mathrm{C}$. Cladosporium sp. (to be used in biossay) was stored on tube slants on malt extract agar $(30 \mathrm{~g}$ malt extract, $15 \mathrm{~g}$ agar, $1 \mathrm{~L} \mathrm{H}_{2} 0$ ) at $4^{\circ} \mathrm{C}$. Alternaria brassicae was aseptically transferred from slants to Petri dishes containing $\mathrm{V}$-8 juice agar. The cultures were allowed to grow in the clark at room temperature for 10-12 d and then stored at $4^{\circ} \mathrm{C}$. Inoculum was prepared by washing the conidia from the plate with $10 \mathrm{~mL}$ of sterile, distilled water. The resulting aqueous suspension (10 000-20 000 spores $\mathrm{mL}^{-1}$ ) was used to inoculate liquid media. Alternaria brassicae was grown in V-8 juice medium $(200 \mathrm{~mL}$ filtered $\mathrm{V}$-8 juice, $0.75 \mathrm{~g}$ $\mathrm{CaCO}_{3}, 800 \mathrm{~mL} \mathrm{H}_{2} 0$ ). The cultures (500 $\mathrm{mL}$ liquid medium in $1 \mathrm{~L}$-Fernback flask) were kept in the dark at room temperature under still-culture conditions. The fungus was harvested after $12 \mathrm{~d}$. The mycelium was separated from the broth by gravity filtration through cheese cloth. This mycelium was blended with sterile distilled water to obtain a suspension which was used in phytoalexin-elicitation experiments as follows.

\section{Phytoalexin elicitation}

Detached plant material $(1 \mathrm{~kg}$ leaves and in some cases whole plants without roots but with flowers and siliques) was dipped into a mycelial suspension 
and then placed in a humid chamber in plastic trays lined with moist paper towels and covered with clear polyethylene sheets. The control was dipped in distilled water and also placed in a humid chamber. The plant material was brought from the greenhouse and the field, and incubated on a laboratory bench at room temperature under continuous white fluorescent light for $5 \mathrm{~d}$. Phytoalexins were extracted from the plant material before senescence occurred, and saprophytic growth of $A$. brassicae took place.

\section{Multiwell method}

The isolation of active metabolites was bioassay-directed as described by Trifonov et al. (1992). The sample was sterilized by filtration through a 0.22 $\mu \mathrm{m}$ nylon membrane. A $200 \mu \mathrm{L}$ sample of the fraction to be bioassayed was applied directly to the well of the multiwell plate (6-well, flat bottom, Falcon 3046) using a micropipette. The solvent was evaporated in a sterile fumehood for $3 \mathrm{~h}$. The inoculum was obtained from the growing edge of a colony of Cladosporium sp. in malt agar Petri dishes. After $4 \mathrm{~d}$ of growth at room temperature, a plug $(7 \mathrm{~mm}$ diam) cut from this culture was placed in each well of the multiwell plate. Three replicates for each fraction and the solvent (control) were evaluated in each multiwell plate. This procedure was repeated for all fractions which showed the same $R_{f}$ value at each chromatographic step. Inhibition in the radial growth of Cladosporium sp. relative to the control was regarded as a positive result.

\section{Isolation of active metabolites}

Five $d$ after inoculation, the leaves were macerated in a Waring blender with methanol-water $(7: 3,12 \mathrm{~L})$. The filtered extract was concentrated under reduced pressure to $500 \mathrm{~mL}$, water $(100 \mathrm{~mL})$ was added and the solution was extracted with ethyl acetate $(3 \times 500 \mathrm{~mL})$. This extract was washed with $5 \%$ aqueous $\mathrm{HCl}$, then made basic with aqueous $\mathrm{NH}_{4} \mathrm{OH}$ and extracted with dichloromethane. Removal of the solvent left a viscous oil $(0.6 \mathrm{~g})$. Flash chromatography of the crude extract afforded a mixture of three compounds $\left(R_{f}=0.35\right.$ -
$0.50,2 \%$ methanol in dichloromethane). HPMPLC (RP-18, 20-40 $\mu \mathrm{m}$ ) using $60 \%$ aqueous methanol on this mixture afforded camalexin and 6-methoxycamalexin. HPLC $\left(\mu\right.$ Bondpak $^{\mathrm{TM}} \mathrm{C}-18,7.8 \mathrm{x}$ $300 \mathrm{~mm}, 125 \AA$ ) using $50 \%$ aqueous methanol afforded $\mathrm{N}$-methylcamalexin.

The camalexin (1) and 6-methoxycamalexin (2), as shown on Fig. 1, were identified by comparison ( ${ }^{1} \mathrm{H} N M R, I R$, UV) with authentic samples (available in our laboratories, Browne et al. 1991).

$\mathrm{N}$-methylcamalexin. ${ }^{1} \mathrm{H} \mathrm{NMR}\left(\mathrm{CDCl}_{3}\right)$ : $87.74(\mathrm{~S}, \mathrm{H}-2), 8.16$ (dd, J $=8,1 \mathrm{~Hz}$, $\mathrm{H}-4), 7.30(\mathrm{~m}, \mathrm{H}-5), 7.35(\mathrm{~m}, \mathrm{H}-6), 7.45$ (dd, J = 8, $1.5 \mathrm{~Hz}, \mathrm{H}-7$ ), $7.8(\mathrm{~d}, \mathrm{~J}=2.5$, $\left.\mathrm{H}-4^{\prime}\right), 7.20\left(\mathrm{~d}, \mathrm{~J}=2.5 \mathrm{~Hz}, \mathrm{H}-5^{\prime}\right), 3.86$ (s, $3 \mathrm{H}, \mathrm{N}-\mathrm{CH} 3$ ); Calculated for $\mathrm{C}_{12} \mathrm{H}_{10} \mathrm{~N}_{2} \mathrm{~S}$, 214.2844: found 214.2840 amu.

\section{RESULTS AND DISCUSSION}

In bioassay, the activity was found to reside in the basic material. Flash chromatography of the basic fraction followed by medium pressure liquid chromatography on reversed phase silica gel provided the two major components. HPLC of the residues provided small amounts of a third component.

The major component $\left(\mathrm{R}_{\mathrm{f}}=0.35\right)$ had a molecular formula of $\mathrm{C}_{11} \mathrm{H}_{8} \mathrm{~N}_{2} \mathrm{~S}$ as determined by EIMS. Absorption at 3430 $\mathrm{cm}^{-1}$ in the IR spectrum suggested the presence of an $\mathrm{NH}$ group. This observation is consistent with the UV spectrum $\left(\lambda_{\max }=214,274,318\right)$ for an indole moiety. The ${ }^{1} H$ NMR showed seven aromatic signals at $\delta 8.68,7.26,7.18$, $6.93,7.77$, and 7.17 and a broad signal at $\delta 9.0$ for the indolic (exchangeable) hydrogen.

In NOE experiments, the presence of a 3-substituted indole moiety was detected. The hydrogens at $\delta 7.3(\mathrm{H} 2)$ and $\delta 6.9(\mathrm{H} 7)$ exhibited enhancement upon irradiation of the $\mathrm{N}-\mathrm{H}$ signal (88.6). Homodecoupling experiments on the spin system $\mathrm{H}^{\prime}{ }^{\prime}-\mathrm{H}^{\prime}$ in the thiazole moiety showed the appropriate coupling constants $(\mathrm{J} 4,5=3 \mathrm{~Hz}$ ) (Jackman and Sternhell 1969). Therefore, the presence of a 2-substituted thiazole was 


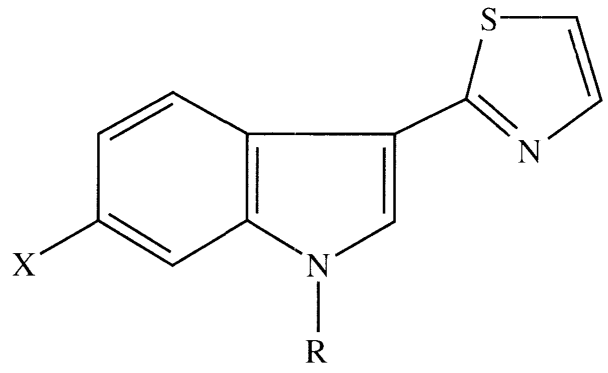

(1) $\mathrm{R}=\mathrm{X}=\mathrm{H}$

(2) $\mathrm{R}=\mathrm{H}, \mathrm{X}=\mathrm{OCH}_{3}$

(3) $\mathrm{R}=\mathrm{CH}_{3}, \mathrm{X}=\mathrm{H}$

Figure 1. Structures of camalexin (1), 6-methoxycamalexin (2), and N-methylcamalexin (3).

substantiated. Comparison IR, ${ }^{1} \mathrm{H}$ NMR, ${ }^{13} \mathrm{C}$ NMR spectra of this compound with an authentic sample of camalexin (1) confirmed the identity (Fig. 1).

The second compound showed a molecular formula $\mathrm{C}_{12} \mathrm{H}_{10} \mathrm{~N}_{2} \mathrm{SO}$, suggesting an additional methoxy group. Indeed, its ${ }^{1} H$ NMR showed a singlet at 83.88 and ${ }^{13} \mathrm{C}$ NMR showed a new signal at 855.7 . Absorption at higher wavelength in the UV spectrum was consistent with this observation. The relative position of a methoxy group on the aromatic ring was determined by NOE experiments. The hydrogens at $\delta 6.8$ and $\delta 7.7$ exhibited enhancement upon irradiation of the signal at $\delta 8.6$ $(\mathrm{N}-\mathrm{H})$. In addition, signals at $\delta 6.94$ and $\delta 6.87$ showed 2.8 and $3.2 \%$ NOE, respectively, upon irradiation of the signal at $\delta 3.88$ (methoxy group). Comparisons with an authentic sample of 6methoxycamalexin (2) completed the identification (Fig. 1).

Further analysis of the crude organic extract by HPLC (RP-C18, $50 \%$ aqueous methanol) showed the presence of a third compound. The molecular formula $\mathrm{C}_{12} \mathrm{H}_{10} \mathrm{~N}_{2} \mathrm{~S}$ indicated the addition of one methyl group to camalexin. The main difference observed in the ${ }^{1} \mathrm{H}$-NMR of this compound, compared with the two other camalexins, was the presence of an $\mathrm{N}$-methyl signal at $\delta 3.86$. The lack of an O-methyl signal and the similarity of the remainder of the ${ }^{1} \mathrm{H}$ NMR spectrum with that of camalexin (1), suggested that this minor metabolite possesses the structure (3) (N-methylcamalexin) (Fig. 1). This compound has not been reported previously.

None of the compounds 1, 2, or 3 were isolated from plant material in the control experiment. These compounds satisfy the definition of phytoalexins (Paxton 1981) in C. bursa-pastoris as they are antimicrobial and are accumulated in the plant after challenge by the pathogen. Also, they resemble other phytoalexins from plants of the family Brassicaceae in containing an indole moiety and sulphur (Gross 1993).

Some research has been done on the role of camalexin in the host-defense systems of $C$. sativa and $A$. thaliana (Conn et al. 1988, 1994; Jejelowo et al. 1991; Rogers et al. 1996; Tsuji et al. 1992). Camalexin is the major phytoalexin in C. bursapastoris and is associated with high degrees of resistance to $A$. brassicae and $A$. brassicicola (Conn et al. 1988; Jejelowo et al. 1991; Sigareva and Earle 1997). It has also been shown to be toxic to $A$. brassicae (Conn 1991; J.P. Tewari and P. Kutschy, unpublished data), A. solani (Jejelowo 1995), and Rhizoctonia solani Kühn (Conn et al. 1994) in in vitro studies. $E_{50}$ for inhibition of conidial germtube growth of $A$. brassicae is approximately 
$6 \mu \mathrm{g} \mathrm{mL}^{-1}$ and the MIC (minimum inhibitory concentration) for complete inhibition of germtube growth is $80 \mu \mathrm{g}$ $\mathrm{mL}^{-1}$ (Jejelowo et al. 1991). Low yields of phytoalexins, such as 6-methoxycamalexin and $\mathrm{N}$-methylcamalexin have so far not permitted such studies.

\section{ACKNOWLEDGEMENTS}

This work was supported through research grants from the Natural Sciences and Engineering Research Council of Canada to W.A. Ayer and J.P. Tewari.

\section{REFERENCES}

Ayer, W.A., P.A. Craw, Y-t Ma, and S. Miao. 1992. Synthesis of camalexin and related phytoalexins. Tetrahedron $48: 2919$ 2924.

Bonfils, A.-C., S.C. Gleddie, J.A. Webb, and W.A. Keller. 1991. Plant regeneration from cell suspension and protoplast cultures of Capsella bursa-pastoris (L.) Medic. Pages $370-374$ in Proc. GCIRC $8^{\text {th }}$ Int. Rapeseed Cong., Saskatoon, Saskatchewan, Canada.

Browne, L.M., K.L. Conn, W.A. Ayer, and J.P. Tewari. 1991. The camalexins: new phytoalexins produced in the leaves of Camelina sativa (Cruciferae). Tetrahedron 47 : 3909-3914.

Conn, K.L. 1991. Phytoalexin production in crucifers. Ph.D. Thesis, Department of Plant Science, University of Alberta, Edmonton, Alberta, Canada. 151 pp.

Conn, K.L., J.P. Tewari, and J.S. Dahiya. 1988. Resistance to Alternaria brassicae and phytoalexin-elicitation in rapeseed and some other crucifers. Plant Sci. 56 : 21-25.

Conn, K.L., L.M. Brown, J.P. Tewari, and W.A. Ayer. 1994. Resistance of Rhizoctonia solani and presence of antimicrobial compounds in Camelina sativa roots. J. Plant Biochem. Biotech. 3 : 125-130.

Gross, D. 1993. Phytoalexins of the Brassicaceae. J. Plant Dis. Prot. $100: 433-442$.

Jackman, L.M., and S. Sternhell. 1969. Applications of nuclear magnetic resonance in organic chemistry. Pergamon Press, Oxford. 307 pp.
Jejelowo, O.A. 1995. Effects of camalexin on germination and germ tube growth of Alternaria solani. Phytopathology 85 : 1177 (Abstract).

Jejelowo, O.A., K.L. Conn, and J.P. Tewari. 1991. Relationship between conidial concentration, germling growth, and phytoalexin production by Camelina sativa leaves inoculated with Alternaria brassicae. Mycol. Res. 95 : 928-934.

Paxton, J.D. 1981. Phytoalexins - a working redefinition. Phytopathol. Z. 101 : 106109.

Pedras, M.S.C., A.Q. Khan, and J.L. Taylor. 1997. Phytoalexins from Brassicas: overcoming plant's defenses. Pages 155166 in P.A. Hedin, R.M. Hollingworth, E.P. Masler, J. Miyamoto, and D.G. Thompson (eds.), Phytochemicals for pest control. ACS Symposium Series 658.

Rogers, E.E., J. Glazebrook, and F.M. Ausubel. 1996. Mode of action of the Arabidopsis thaliana phytoalexin camalexin and its role in Arabidopsis-pathogen interactions. Mol. Plant-Microbe Interact. $9: 748-757$.

Sigareva, M., and E.D. Earle. 1997. Capsella bursa-pastoris regeneration of plants from protoplasts and somatic hybridization with rapid cycling Brassica oleracea. Cruciferae Newsletter 19:57-58.

Tewari, J.P. 1991. Resistance to Alternaria brassicae in crucifers. IOBCMPRS Bull. 14 : 154-161.

Tewari, J.P., and K.L. Conn. 1993. Reactions of some wild crucifers to Alternaria brassicae. IOBC/WPRS Bull. $16: 53-58$.

Trifonov, L.S., P. Chakravarty, Y. Hiratsuka, and W.A. Ayer. 1992. Antifungal activity of metabolites of Peniophora polygonia against the aspen decay fungus Phellinus tremulae. Eur. J. For. Pathol. 22 : 441-448.

Tsuji, J., E.P. Jackson, D.A. Gage, R. Hammerschmidt, and S.C. Sommerville. 1992. Phytoalexin accumulation in Arabidopsis thaliana during the hypersensitive reaction to Pseudomonas syringae pv. syringae. Plant Physiol. 98: 1304-1309.

Tsuji, J., M. Zook, S.C. Sommerville, R.L. Last, and R. Hammerschmidt. 1993. Evidence that tryptophan is not a direct biosynthetic intermediate of camalexin in Arabidopsis thaliana. Physiol. Mol. Plant Pathol. 43 : 221-229. 